\title{
Pengaruh Pemberian Kompensasi Karyawan terhadap Kepuasan dalam kinerja untuk Meningkatkan Kualitas Pelayanan
}

\author{
Agus Dwi Cahya \\ Universitas Sarjanawiyata Tamansiswa \\ agusdc@ustjogja.ac.id \\ Riky Artya S \\ Universitas Sarjanawiyata Tamansiswa \\ rikyartya@gmail.com

\section{Syahril Asfiah N} \\ Universitas Sarjanawiyata Tamansiswa \\ syahrilasfiah@gmail.com

\section{Pandu Sinawung Jati} \\ Universitas Sarjanawiyata Tamansiswa \\ sinawung@gmail.com
}
Abstrak
Penelitian ini bertujuan untuk mengetahui pengaruh pemberian kompensasi terhadap kepuasan dalam kinerja guna meningkatkan kualitas pelayanan. Kompensasi merupakan peranan sangat penting dalam suatu usaha dikarenakan mampu memberi motivasi bagi karyawan untuk lebih giat dalam bekerja, oleh karena itu, harus dilakukan secara profesional agar terwujud keseimbangan antara kebutuhan pegawai dan tuntutan. Penelitian ini bersifat deskriptif kualitatif. Proses pengambilan data dilakukan pada warung Penyetan Aprex dimana populasi dan sampel didapat dengan cara melakukan wawancara terhadap pemilik dan karyawan dari tempat tersebut. Teknik analisis data yang dipakai adalah metode induktif, melalui penyajian data tersebut diharapkan data akan terorganisasikan dan tersusun dalam pola hubungan, sehingga akan semakin mudah dipahami. Hasil penelitian ini menunjukan bahwa pemberian kompensasi di Penyetan Aprex ini berpengaruh positif dan signifikan terhadap kinerja karyawan. Hasil temuan penelitian ini mengungkapkan bahwa kompensasi berdampak positif terhadap kepuasan kerja pekerja.

Kata Kunci Kompensasi, Kepuasan, Kinerja, Kualitas Pelayanan

\section{PENDAHULUAN}

Perkembangan suatu usaha sangatlah bergantung pada produktifitas tenaga kerja yang ada pada usaha tersebut. Salah satu untuk meningkatkan produktifitas kerja karyawan adalah dengan cara menetapkan pemberian kompensasi yang adil dan layak pada karyawan tersebut atas prestasi kerja yang dicapai. Dengan demikian pemberian kompensasi dalam usaha harus diatur dengan baik, jadi dalam mengembangkan dan 
menerapkan suatu sistem kompensasi tertentu kepentingan karyawan mutlak untuk diperhitungkan.

Penyetan Aprex merupakan sebuah usaha yang berada di daerah Kasihan, Bantul yang bergerak dibidang kuliner yang dimana tentu mempunyai karyawan sebagai aset usaha yang harus diperhatikan, sehingga usaha tidak kehilangan karyawan-karyawan yang memiliki produktifitas kerja yang baik. Dalam pengamatan sementara penulis di objek penelitian bahwa Penyetan Aprex belum optimal. Adapun indikator dari hal itu adalah pemberian kompensasi apakah berpengaruh terhadap kepuasan kerja dan kepuasan terebut dapat berpengaruh terhadap meningkatnya kualitas penjualan dari penyetan Penyetan Aprex tersebut.

Pemberian kompensasi bagi karyawan merupakan salah satu cara motivasi yang berguna untuk memuaskan kebutuhan ekonomi para karyawan serta dapat menunjang bagi tercapainya hubungan yang harmonis antara karyawan dan perusahaan tersebut(Azhar, Nurdin, \& Siswadi, 2020). Kompensasi adalah pemberian imbalan yang berwujud dan tidak berwujud yang diterima karyawan sebagai bagian dari hubungan kerja. Kompensasi sebagai pendekatan sistematis untuk memberikan nilai moneter kepada karyawan dalam pertukaran untuk pekerjaan yang dilakukan.

Dengan memperhatikan hal tersebut penelitian ini bertujuan untuk menemukan seberapa penting kompensasi tersebut bagi karyawan untuk meningkatkan produkstifitasnya. Selain itu, tujuannya tidak hanya untuk memberikan pemulihan cepat dan tertentu kepada karyawan yang terluka, tetapi juga untuk memastikan kewajiban yang terbatas dan menentukan bagi pemberi kerja(Darma, Wicaksono, Sanica, \& Abiyasa, 2019). Dari penjelasan diatas Penulis tertarik untuk mengadakan penelitian yang kemudian akan dituangkan dalam bentuk tulisan ilmiah yang berjudul Pemberian kompensasi terhadap kepuasan dalam kinerja untuk meningkatkan kualitas penjualan ( penyetan aprex Kasihan Bantul)".

Rumusan masalah apakah pemberian kompensasi berpengaruh terhadap kepuasan dalam bekerja dan apakah kepuasan kinerja dapat mempengaruhi kualitas penjualan

Kemudian tujuan penelitian untuk mengetahui pemberian kompensasi berpengaruh terhadap kepuasan dalam bekerja dan untuk mengetahui kepuasan kinerja dapat mempengaruhi kualitas penjualan

\section{LANDASAN TEORI}

\section{Kompensasi}

Pemberian kompensasi dinilai merupakan kewajiban suatu perusahaan maupun usaha kecil masyarakat. Di sisi lain, tuntutan perusahaan terhadap pegawai juga harus diimbangi dengan pemberian kompensasi (Mondiani, 2012). Mereka akan puas apabila tingkat kompensasi sebanding dengan tingkat kompensasi aktual, atau tidak puas apabila tingkat kompensasi aktual lebih kecil daripada tingkat kompensasi yang semestinya mereka terima. Kompensasi adalah semua pendapatan yang berbentuk uang baik langsung maupun tidak langsung sebagai imbalan atau jasa yang diberikan kepada perusahaan. (Kasenda, 2013)

\section{Kepuasan Kerja}

Kepuasaan kerja adalah tingkat kesenangan yang dirasakan oleh seseorang atas peranan atau pekerjaannya dalam organisasi. Untuk menciptakan kepuasan kerja dalam diri karyawan, perlu diketahui faktor-faktor yang mempengaruhinya (Hidayat, 2015). Jadi 
kepuasaan kerja menyangkut psikologis individu didalam organisasi, yang diakibatkan oleh keadaan yang ia rasakan dari lingkungannya. Demikian Guion mendefinisikan kepuasan kerja merupakan sejauh mana kebutuhan individu terpenuhi dan sejauh mana individu menganggap kepuasan itu berasal dar situasi kerja totalnya dalam (Darma et al., 2019) Seseorang dengan tingkat kepuasan kerja yang tinggi memiliki perasaan-perasaan positif tentang pekerjaan tersebut. Jika sebuah individu dapat menyelesaikan pekerjaannya akan menjadi kepuasan tersendiri. Menurut Mangkunegara dalam (Nabawi, 2019) kepuasan kerja adalah tingkat afeksi seorang pekerja terhadap pekerjaan dan situasi pekerjaan yang berkaitan dengan sikap pekerja atas pekerjaannya.

\section{Kinerja Karyawan}

Kinerja sering dihubungan atau didefinisikan sebagai kegiatan yang dilakukan untuk mencapai sebuah tujuan. Didalam sebuah perusahaan, kinerja karyawan sangat diperlukan untuk mencapai tujuan dari perusahaan tersebut. Maka dari itu, sering kita mendengar aset terbaik perusahaan adalah karyawan. Kinerja pada dasarnya adalah suatu yang berikan karyawan dalam menentukan seberapa banyak mereka memberikan kontribusi pada perusahaan dalam bentuk hasil produksi maupun pelayanan yang disajikan (Daspar, 2020). Kinerja yang baik merupakan suatu tindakan untuk tercapainya tujuan dari organisasi sehingga diperlukan upaya untuk meningkatkan kinerja (Rozalia, 2015). Akan tetapi rendahnya kinerja karyawan juga tidak bagus bagi perusahaan dan masalah ini tentu banya juga di jumpai disetiap perusahaan. Maka dari itu semestinya dalam bekerja seorang karyawan haruslah bersikap profesional dan memegang tanggung jawab yang diberikan oleh perusahaan agar tercipatanya kinerja yang baik.

\section{Kualitas Pelayanan}

Kualitas pelayanan dapat dilihat dengan cara membandingkan persepsi para konsumen tehadap pelayanan yang mereka terima. Menurut Lewis \& Booms Tjiptono dan Chandra, dalam (Atmaja, 2018) kualitas layanan adalah ukuran seberapa bagus tingkat layanan yang diberikan mampu sesuai dengan ekspetasi pelanggan.

\section{Kerangka Pemikiran}

Kerangka berpikir ini bertujuan untuk menggambarkan jalan pikir peneliti kepada pembaca agar mengetahui hasil dari proses penelitian. Kerangka pikir tersebut menjelaskan hubungan antara variabel dependen dan independen.

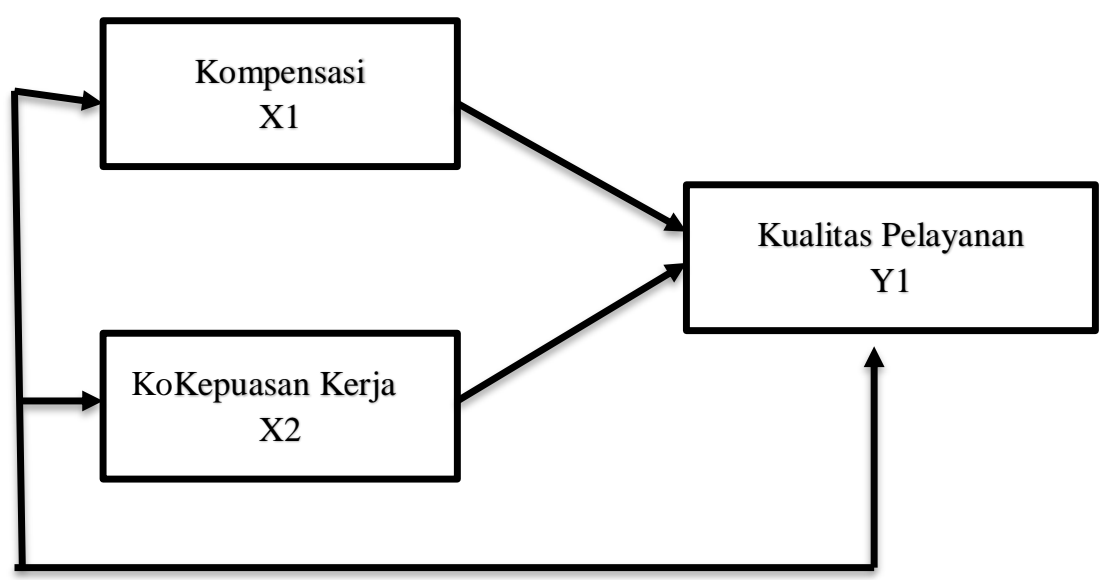

Gambar. 1 kerangka berpikir 


\section{METODOLOGI PENELITIAN}

Penelitian ini menggunaan penelitian kualitatif karena peneliti terjun langsung meneliti dan melihat kondisi lapangan. Dalam penelitian kualitatif, konseptualisasi, kategorisasi, dan deskripsi dikembangkan atas dasar "kejadian" yang diperoleh ketika kegiatan lapangan berlangsung. Karenanya, antara kegiatan pengumpulan data dan analisis data tidak mungkin dipisahkan satu sama lain (Rijali, 2019). Menurut pendapat tersebut dapat disimpulan bahwa peneliti berusaha menarik data dengan sebenarnya dan tanpa dibuat-buat dikarenakan peneliti terjun langsung ke lapangan untuk mengetahui sampel yang diteliti.

Penelitian kualitatif adalah riset yang bersifat deskriptif dan cenderung menggunakan metode induktif. Selain itu pendekatan kualitatif digunakan untuk memperoleh gambaran diskriptif yang lebih luas mengenai fenomena yang diamati. Karena, pendekatan kualitatif dipandang mampu menggali pemaknaan terhadap fenomena secara lebih mendalam.

Penelitian ini berlokasi di Penyetan Aprex yang beralamat di Onggobayan, Ngestiharjo, Kasihan, Bantul. Untuk penelitian sendiri dilakukan pada tanggal 4 April 2021.

Untuk menjamin kevalidan data dilakukan Teknik pengumpulan data yang digunakan dalam penelitian ini adalah:

1. Wawancara

Wawancara adalah suatu cara mengumpulkan data dengan dialog langsung dengan narasumber atau responden untuk memperoleh informasi dari terwawancara.

2. Observasi

Observasi adalah pengamatan secara langsung yang meliputi kegiatan pemusatan perhatian terhadap suatu objek dengan menggunakan seluruh alat indera

3. Pencatatan

Pencatatan adalah bukti tulis hasil obervasi dari data yang diambil sewaktu penelitian. Responden yang menjadi narasumber ialah karyawan dari bapak Apri Yanto di penyetan tersebut yang berjumlah sekitar 15 orang.

\section{HASIL PENELITIAN}

Pemberian kompensasi terhadap karyawan tentunya akan membuat para karyawan termotivasi untuk meningkatkan kualitas penjualannya. Hal ini sesuai dengan pendapat Mabaso, dalam (Darma et al., 2019) bahwa kompensasi memainkan peran penting dalam organisasi yang ingin mencapai tujuan dan sasaran yang ditetapkan. Maka dari itu pemberian kompensasi akan memberikan kepuasan kerja tingkat rasa puas individu bahwa mereka dapat imbalan yang setimpal dari bermacam-macam aspek situasi pekerjaan dari organisasi tempat mereka bekerja dan akan mempengaruhi kinerja karyawan untuk lebih giat meningkatkan kualitas penjualan tersebut.

Pemberian kompensasi Di Penyetan Aprex ini berpengaruh positif dan signifikan terhadap kinerja karyawan (Salisu et al., 2015). Konsisten dengan hasil penelitian sebelumnya oleh temuan penelitian ini mengungkapkan bahwa kompensasi berdampak positif terhadap kepuasan kerja para pekerja. Sesuai dengan hasil temuan penelitian ini mengungkapkan bahwa kompensasi berdampak positif terhadap kepuasan kerja pekerja. Berikut adalah hasil wawancara dengan dengan para karyawan di Penyetan Aprex.

1. Apakah bentuk kompensasi dari UMKM Penyetan Aprex ini? Kompensasi yang biasa diberikan oleh pemilik usaha kepada kami selaku karyawan yaitu berupa upah tambahan diluar upah tetap setiap bulannya. Jumlah kompensasi yang diberikan juga bervariasi setiap pembagiannya tergantung pendapatan yang masuk. (Wawancara) 
2. Bagaimana sistem pemberian kompensasi? Sistem yang digunakan dalam pemberian kompensasi pada UMKM Penyetan Aprex diberikan berdasarkan waktu karyawan bekerja dan banyaknya pemasukan yang dihasilkan. Apabila dalam kurun waktu satu bulan pendapatan yang dihasilkan mencapai target maka karyawan akan mendapatkan kompensasi upah tambahan dari pemilik. Jadi, tidak setiap bulan karyawan dapat memperoleh kompensasi. (Wawancara)

3. Apakah kompensasi yang diberikan sekiranya dapat meningkatkan pelayanan?Pemberian kompensasi kepada karyawan dapat meningkatkan pelayanan dikarenakan adanya kompensasi tambahan akan membuat karyawan lebih rajin dan giat dalam melakukan pekerjaannya. Karyawan juga akan memberikan pelayanan yang terbaik kepada konsumen dengan tujuan memberikan kesan yang baik sehingga konsumen akan nyaman dan kembali. (Wawancara)

4. Bagaimana cara karyawan meningkatkan mutu pelayanan setelah adanya kompensasi yang diberikan oleh pemilik UMKM? Guna meningkatkan mutu pelayanan dan mendapat kompensasi dari tercapainya target pemasukan usaha, karyawan akan memberikan servis yang maksimal kepada konsumen. Servis yang diberikan karyawan antara lain berupa keramahan dalam berkomunikasi kepada konsumen, cepat dan tanggap dalam memberikan layanan kepada konsumen, serta rajin dan selalu menjaga kebersihan warung makan agar konsumen merasa nyaman (Wawancara)

Dari hasil wawancara peneliti terhadap narasumber di UMKM Penyetan Aprex ini menunjukkan bahwa manfaat kompensasi tentunya tidak dirasakan oleh karyawan saja akan tetapi juga memberi manfaat bagi pemilik serta para pemebeli yang datang ketempat tersebut. Selain itu, manajemen kompensasi juga dapat mempengaruhi kepuasan karyawan ketika upah, resiko dan tanggung jawab bisa seimbang dan adil, maka akan menciptakan kepuasan yang tinggi, hal ini sesuai dengan teori kesetaraan atau keadilan yaitu pembandingan dengan pekerjaan dan gaji yang hasilkan oleh karyawan lain sehingga menghasilkan kualitas pelayanan yang bagus. Kualitas pada dasarnya terkait dengan pelayanan yang terbaik, yaitu suatu sikap atau cara karyawan dalam melayani pelanggan atau masyarakat secara memuaskan (Angliawati, 2016).

\section{PEMBAHASAN}

Jika dilihat dari Kompensasi sebagai bentuk penghargaan terhadap kinerja karyawan dalam suatu usaha atau perusahaan berperan penting guna mengembangkan usaha tersebut. Selain untuk menambah motivasi karyawan dalam bekerja yang kemudian berpengaruh terhadap kinerja karyawan sehingga dapat mempertahankan dan menambah pemasukan suatu usaha, juga sebagai wujud kepedulian terhadap karyawan. Dalam penelitian ini membuktikan bahwa dengan adanya kompensasi, karyawan secara naluri juga akan meningkatkan mutu pelayanan mereka dalam bekerja. Dengan demikian, kualitas pelayanan UMKM Penyetan Aprex dipandang baik oleh pelanggan. Kompensasi yang diberikan juga bervariasi, hal itu berbanding lurus dengan seberapa banyak pendapatan yang masuk ke dalam usaha. Semakin banyak pendapatan masuk, semakin banyak juga kompensasi yang diterima oleh karyawan.

\section{KESIMPULAN}

\section{Kesimpulan}

Berdasarkan penelitian yang telah dilakukan, kami memperoleh kesimpulan sebagai berikut: 
1. Kompensasi mampu member pengaruh yang cukup besar terhadap para karyawan. Pemberian kompensasi yang tepat dapat meningkatkan kinerja serta meningkatkan kualitas pelayanan. Pada UMKM Penyetan Aprex, dengan adanya pemberian kompensasi, karyawan akan termotivasi untuk meningkatkan kualitas pelayanan sehingga akan membuat pelanggan yang berkunjung merasa nyaman dan mempunyai keinginan untuk berkunjung kembali di lain waktu.

2. Dengan adanya kompensasi, karyawan yang bekerja akan merasa puas dan akan memunculkan naluri karyawan untuk lebih meningkatkan kualitas pelayanannya. Dengan demikian, pengunjung akan merasakan kepuasan dari pelayanan yang diterimanya sehingga secara tidak langsung hal tersebut merupakan salah satu keberhasilan sebuah tempat usaha yang mempunyai tujuan untuk meningkatkan pendapatan dengan cara memberikan pelayanan yang sebaik mungkin.

\section{Saran}

Pemberian kompensasi memang berpengaruh terhadap kualitas pelayanan, terbukti dari hasil wawancara yang menggambarkan karyawan mampu meningkatkan pelayanan. Maka dari itu pemilik perlu memberikan timbal balik berupa kompensasi yang sekiranya sesuai dengan kinerja karyawan. Berdasarkan kesimpulan diatas, maka dapat diberikan saran-saran yang sekiranya dapat digunakan sebagai bahan pertimbangan suatu usaha dalam upaya meningkatkan kinerja karyawan.

1. Kompensasi yang diberikan oleh Penyetan Aprex hendaknya terus diperhatikan dan ditingkatkan lagi guna menunjang kinerja karyawan untuk semakin lebih baik dan mampu berpengaruh kepada meningkatnya pendapatan bagi warung itu sendiri.

2. Item variabel kompensasi yang selama ini dinilai positif bagi karyawan seperti, jumlah gaji yang akan diterima setiap bulan, jumlah komisi yang akan diterima setiap bulan, komisi yang diterima apakah dapat memenuhi kebutuhan sehari-hari karyawan lebih diperhatikan

\section{UCAPAN TERIMA KASIH}

Atas Berkat Rohmat Alloh Yang Maha Kuasa kami selaku penulis dapat merealisasikan penyusunan jurnal penelitian ini dengan judul Pengaruh Pemberian Kompensasi Karyawan Terhadap Kepuasan Dalam Kinerja Untuk Meningkatkan Kualitas Pelayanannya. Penulisan jurnal ini merupakan salah satu syarat sebagai tugas akhir Mata Kuliah Kewirausahaan. Terwujudnya jurnal ini tidak terlepas dari bimbingan Bapak Agus Dwi Cahya, S.Pd., M.M. selaku dosen pengampu Mata Kuliah Kewirausahaan. Dukungan dari rekan-rekan mahasiswa Program Studi Manajemen Fakultas Ekonomi Universitas Sarjanawiyata Tamansiswa juga sangat berarti bagi kami selaku tim penulis. Tidak lupa kami juga mengucapkan terima kasih kepada seluruh pihak-pihak dari UMKM Penyetan Aprex yang dengan sukarela meluangkan waktu untuk dapat kami observasi dan wawancara sebagai salah satu cara untuk menyusun jurnal ini. Semoga dengan tersusunnya jurnal ini dapat menjadi salah satu sumber referensi dikemudian hari.

\section{DAFTAR PUSTAKA}

Angliawati, R. Y. (2016). Peran Remunerasi Terhadap Kualitas Pelayanan Publik: Theoretical Review. Ecodemica, 4(2), 203-213. Retrieved from http://ejournal.bsi.ac.id/ejurnal/index.php/ecodemica/article/view/801 
Atmaja, J. (2018). Kualitas Pelayanan dan Kepuasan Nasabah Terhadap Loyalitas Pada Bank BJB. Jurnal Ecodemica, 2(1), 49-63. Retrieved from https://ejournal.bsi.ac.id/ejurnal/index.php/ecodemica/article/view/2713

Azhar, M. E., Nurdin, D. U., \& Siswadi, Y. (2020). Pengaruh Disiplin Kerja dan Kompensasi Terhadap Kepuasan Kerja Karyawan. Jurnal Humaniora, 4(1), 46-60.

Darma, G. S., Wicaksono, K., Sanica, I. G., \& Abiyasa, A. P. (2019). Faktor Kompensasi Dan Strategi Gojek Dalam Meningkatkan Kepuasan Kerja Para Driver. JMBI UNSRAT (Jurnal Ilmiah Manajemen Bisnis Dan Inovasi Universitas Sam Ratulangi)., 6(3), 232244. https://doi.org/10.35794/jmbi.v6i3.27105

Daspar, D. (2020). Pengaruh Lingkungan, Motivasi dan Disiplin Kerja Terhadap Kinerja Karyawan. EKOMABIS: Jurnal Ekonomi Manajemen Bisnis, 1(02), 159-166. https://doi.org/10.37366/ekomabis.v1i02.31

Hidayat, R. (2015). Performance Appraisal sebagai Alat Pengukuran Kepuasan Kerja Karayawan. Ilman, 3(1), 1-8.

Kasenda, R. (2013). Kompensasi Dan Motivasi Pengaruhnya Terhadap Kinerja Karyawan Pada Pt. Bangun Wenang Beverages Company Manado. Jurnal Riset Ekonomi, Manajemen, Bisnis Dan Akuntansi, 1(3), 853-859. https://doi.org/10.35794/emba.v1i3.1894

Mondiani, T. (2012). Pengaruh Kepemimpinan Transformasional Dan Kompensasi Terhadap Kinerja Karyawan Pt . Pln ( Persero ) Upj Semarang. Jurnal Administrasi Bisnis Volume, 1(1), 46-54.

Nabawi, R. (2019). Pengaruh Lingkungan Kerja, Kepuasan Kerja dan Beban Kerja Terhadap Kinerja Pegawai. Maneggio: Jurnal Ilmiah Magister Manajemen, 2(2), 170183. https://doi.org/10.30596/maneggio.v2i2.3667

Rijali, A. (2019). Analisis Data Kualitatif. Alhadharah: Jurnal Ilmu Dakwah, 17(33), 81. https://doi.org/10.18592/alhadharah.v17i33.2374

Rozalia, N. (2015). PENGARUH MOTIVASI KERJA DAN DISIPLIN KERJA TERHADAP KINERJA KARYAWAN (Studi Kasus Pada Karyawan PT. Pattindo Malang). Jurnal Administrasi Bisnis S1 Universitas Brawijaya, 26(2), 86280.

Salisu, J. B., Chinyio, E., \& Suresh, S. (2015). The impact of compensation on the job satisfaction of public sector construction workers of jigawa state of Nigeria. The Business and Management Review, 6(4), 10-11. 